\title{
Current State, Challenges and Perspectives of Biological Production of Hydrogen in Dark Fermentation Process in Poland
}

\author{
Kamil Kozłowski ${ }^{*}$, Andrzej Lewicki', Krystyna Malińska², Qiao Wei ${ }^{3}$ \\ 1 Institute of Biosystems Engineering, Poznan University of Life Sciences, Wojska Polskiego 50, 60-627 Poznan, \\ Poland \\ 2 Institute of Environmental Engineering, Czestochowa University of Technology, Brzeznicka 60A, \\ 42-200 Czestochowa, Poland \\ ${ }^{3}$ College of Engineering, China Agricultural University, No. 17 Qinghua Donglu, Haidian District, \\ Beijing 100083, China \\ * Corresponding author's e-mail: kamil.kozlowski@up.poznan.pl
}

\begin{abstract}
The increasing demand for electrical energy and environmental concerns associated with conventional means of its generation drive the interest in alternative fuels. Biohydrogen, widely considered as fuel of the future, is one of such alternatives. To date, research results suggest that biological routes are the most promising for hydrogen production, especially dark (hydrogen) fermentation. Hydrogen fermentation can be performed with agricultural and food processing wastes as substrates. In this paper the most important factors influencing dark fermentation are reviewed and analyzed. These are: $\mathrm{pH}$, partial pressure, temperature, and retention time. The biohydrogen generation efficiency is also presented with respect to different substrates. It should be also pointed out that many factors are still unknown; thus, the process requires conducting further research.
\end{abstract}

Keywords: renewable energy sources, biohydrogen, dark fermentation, wastes management, biogas plants

\section{INTRODUCTION}

The energy crisis and intensive degradation of the natural environment lead to the intensification of the search for harmless novel energy carriers. It is commonly acknowledged that the conventional processes of energy production are the cause of irreversible climate changes, global warming and faster depletion of natural resources [Ni et al. 2006]. The research data confirms that the greenhouse effect is a consequence of carbon dioxide emission from the use of fossil fuels [Budzianowski 2011]. Therefore, the search for new technologies of energy generation from alternative energy sources is necessary.

During the last decades, studies focused primarily on using biomass (in direct combustion), liquid biofuels (in esterification and transesterification) and methane (in anaerobic digestion process (AD) for the production of heat. Hydrogen is one of the alternative energy carriers considered as an ecological biofuel of the future. It is characterized by high content of energy per unit of

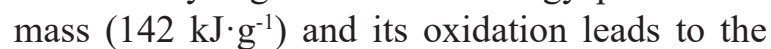
generation of water (steam) besides energy [Guo et al. 2010, Rahman et al. 2016]. It is possible to utilize hydrogen directly in internal combustion engines or fuel cells [Alves et al. 2013, Kotay et al. 2008]. It is commonly used as a reagent in the production of fertilizers, for oil refining and industrial ammonia synthesis. The issues that hinder the wide-scale application of hydrogen as a fuel are related to high costs of its production, and the technical problems associated with its storage and distribution. Commercially, it is produced in a steam reforming process from natural gas and oil and, to a lesser extent, through gasification of coal and water electrolysis [Balat 2008, Hassen Sellami and Loudiyi 2017]. However, as mentioned above, these processes are very energy-consuming and, moreover, they require fossil fuels. The production of hydrogen by biological 


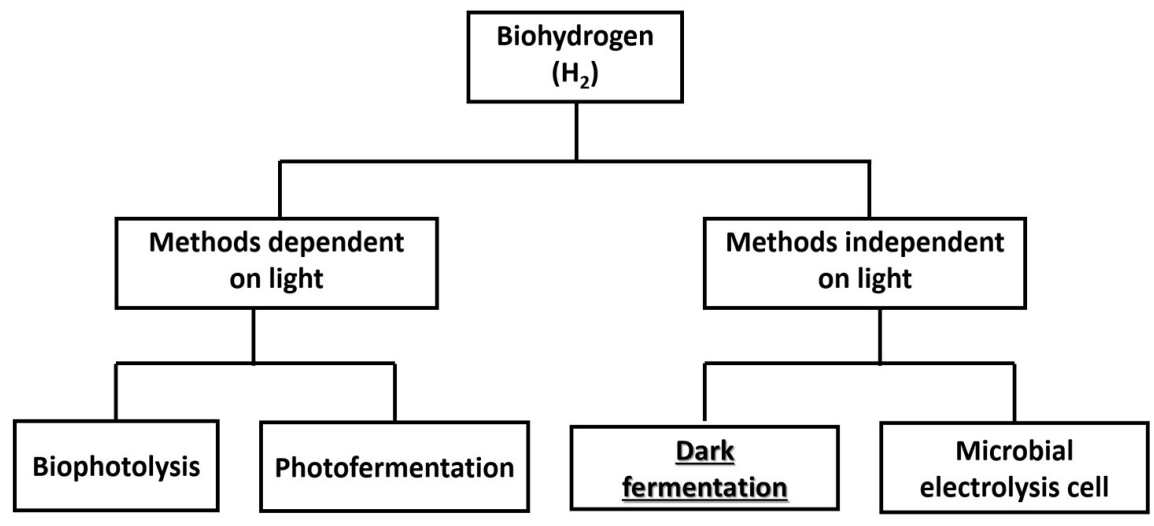

Fig. 1. Biological methods of hydrogen production [Ghimire et al. 2015]

means is thus promising as it does not require large quantities of energy (Figure 1).

The first observations regarding the hydrogen production by algae and bacteria were made over 100 years ago [Jackson and Ellms 1896]. A basic research in this area was carried out in 1929 by Strickland [Strickland 1929], research and development work began in the 1970. The biological processes of hydrogen production include direct biophotolysis of water carried out by algae, indirect biophotolysis of water using cyanobacteria, photofermentation with photosynthetic bacteria and dark fermentation (DF) conducted by anaerobic bacteria [Ghimire et al. 2015]. DF can become one of the important technologies of energy production from organic wastes such as complex agri-food industry by-products that can also be used in AD.

The aim of this paper was to review the current state of knowledge on the possibility of biological hydrogen production in the process of DF and the actual situation of the renewable energy market in Poland. The progress in the studies on the production of biohydrogen worldwide and the possibility of using substrates available in Poland in the process of DF were analyzed.

\section{RENEWABLE ENERGY MARKET IN POLAND}

The adoption of the climate and energy package by the countries of the European Union in March 2007 and the introduction of the Directive 2009/28/EC on the promotion of energy production from renewable sources were aimed at reducing the greenhouse gas emissions and the consumption of conventional fuels. As part of these activities, Poland committed itself that by 2020 the share of renewable energy sources (RES) in the final energy balance would increase to $15 \%$, the energy efficiency to $20 \%$ and greenhouse gas emissions to the atmosphere would decrease by $20 \%$ compared to 1990 . As a consequence of these actions, Parliament of the Republic of Poland adopted the Act on Renewable Energy Sources (AoRES) on February 20, 2015, which entered into force on May 4, 2015. The AoRES [2016] defines the Renewable Energy Source as renewable, non-fossil energy sources including wind energy, solar radiation energy, aerothermal energy, geothermal energy, hydrothermal energy, hydro energy, energy obtained from waves, currents and tides, as well as from biomass, biogas, agricultural biogas and from bioliquids. Table 1 presents the data on the share of RES in the total energy production for Poland and selected European Union countries (2004-2015) as well as the targets assumed for 2020.

Utilization of renewable energy in Poland has been growing systematically since the introduction of the supportive system. It should be noted that approx. $45 \%$ of the energy production from renewable sources - recognized by the Ministry of Economy as RES - is co-incineration of biomass with fossil fuels [Paska and Surma 2014]. According to the data of the Energy Regulatory Office (ERO), which regulates the Polish Energy Market, the total capacity of RES installations in Poland amounts to 8,440.459 MW. Table 2 presents the Energy Regulatory Office data on RES power capacity installed in Poland.

The largest share in the production of electrical energy from RES, excluding co-incineration, is assigned to wind farms (about 5,807,316 MW), which accounts for about $69 \%$ of the total energy production from RES. On the other hand, the lowest power capacity installed is for photovoltaic 
Table 1. Percentage share of renewable energy in gross final energy consumption in European Union countries (in 2004-2015) [Eurostat Statistics Explained 2017]

\begin{tabular}{|c|c|c|c|c|c|c|c|c|c|c|c|}
\hline & 2004 & 2007 & 2008 & 2009 & 2010 & 2011 & 2012 & 2013 & 2014 & 2015 & $\begin{array}{l}\text { Target } \\
(2020)\end{array}$ \\
\hline $\begin{array}{l}\text { EU - } 28 \\
\text { countries }\end{array}$ & 8.5 & 10.4 & 11.0 & 12.4 & 12.9 & 13.2 & 14.4 & 15.2 & 16.1 & 16.7 & 20 \\
\hline Poland & 6.9 & 6.9 & 7.7 & 8.7 & 9.3 & 10.3 & 10.9 & 11.4 & 11.5 & 11.8 & 15 \\
\hline Austria & 22.6 & 27.2 & 28.1 & 29.9 & 30.4 & 30.6 & 31.4 & 32.3 & 32.8 & 33.0 & 34 \\
\hline Belgium & 1.9 & 3.1 & 3.6 & 4.7 & 5.7 & 6.3 & 7.2 & 7.5 & 8.0 & 7.9 & 13 \\
\hline Bulgaria & 9.4 & 9.2 & 10.5 & 12.1 & 14.1 & 14.3 & 16.0 & 19.0 & 18.0 & 18.2 & 16 \\
\hline Croatia & 23.5 & 22.2 & 22.0 & 23.6 & 25.1 & 25.4 & 26.8 & 28.0 & 27.9 & 29.0 & 20 \\
\hline Cyprus & 3.1 & 4.0 & 5.1 & 5.6 & 6.0 & 6.0 & 6.8 & 8.1 & 8.9 & 9.4 & 13 \\
\hline Czech Republic & 6.8 & 8.0 & 8.6 & 9.9 & 10.5 & 11.0 & 12.8 & 13.8 & 15.1 & 15.1 & 13 \\
\hline Denmark & 14.9 & 17.8 & 18.6 & 20.0 & 22.1 & 23.5 & 25.7 & 27.4 & 29.3 & 30.8 & 30 \\
\hline Estonia & 18.4 & 17.1 & 18.9 & 23.0 & 24.6 & 25.5 & 25.8 & 25.6 & 26.3 & 28.6 & 25 \\
\hline Finland & 29.2 & 29.6 & 31.3 & 31.3 & 32.4 & 32.8 & 34.4 & 36.7 & 38.7 & 39.3 & 38 \\
\hline France & 9.4 & 10.1 & 11.1 & 12.1 & 12.5 & 11.1 & 13.4 & 14.1 & 14.7 & 15.2 & 23 \\
\hline Germany & 5.8 & 9.1 & 8.6 & 9.9 & 10.5 & 11.4 & 12.1 & 12.4 & 13.8 & 14.6 & 18 \\
\hline Greece & 6.9 & 8.2 & 8.0 & 8.5 & 9.8 & 10.9 & 13.5 & 15.0 & 15.3 & 15.4 & 18 \\
\hline Hungary & 4.4 & 5.9 & 6.5 & 8.0 & 12.8 & 14.0 & 15.5 & 16.2 & 14.6 & 14.5 & 13 \\
\hline Ireland & 2.4 & 3.6 & 4.1 & 5.1 & 5.6 & 6.6 & 7.2 & 7.7 & 8.7 & 9.2 & 16 \\
\hline Italy & 6.3 & 9.8 & 11.5 & 12.8 & 13.0 & 12.9 & 15.4 & 16.7 & 17.1 & 17.5 & 17 \\
\hline Latvia & 32.8 & 29.6 & 29.8 & 34.3 & 30.4 & 33.5 & 35.7 & 37.1 & 38.7 & 37.6 & 40 \\
\hline Lithuania & 17.2 & 16.5 & 17.8 & 19.8 & 19.6 & 19.9 & 21.4 & 22.7 & 23.6 & 25.8 & 23 \\
\hline Luxembourg & 0.9 & 2.7 & 2.8 & 2.9 & 2.9 & 2.9 & 3.1 & 3.5 & 4.5 & 5.0 & 11 \\
\hline Malta & 0.1 & 0.2 & 0.2 & 0.2 & 1.0 & 1.9 & 2.8 & 3.7 & 4.7 & 5.0 & 10 \\
\hline Netherlands & 2.1 & 3.3 & 3.6 & 4.3 & 3.9 & 4.5 & 4.7 & 4.8 & 5.5 & 5.8 & 14 \\
\hline Portugal & 19.2 & 21.9 & 23.0 & 24.4 & 24.2 & 24.6 & 24.6 & 25.7 & 27.0 & 28.0 & 31 \\
\hline Romania & 16.3 & 18.3 & 20.5 & 22.7 & 23.4 & 21.4 & 22.8 & 23.9 & 24.8 & 24.8 & 24 \\
\hline Slovakia & 6.4 & 7.8 & 7.7 & 9.4 & 9.1 & 10.3 & 10.4 & 10.1 & 11.7 & 12.9 & 14 \\
\hline Slovenia & 16.1 & 15.6 & 15.0 & 20.1 & 20.4 & 20.3 & 20.8 & 22.4 & 21.5 & 22.0 & 25 \\
\hline Spain & 8.3 & 9.7 & 10.8 & 13.0 & 13.8 & 13.2 & 14.3 & 15.3 & 16.1 & 16.2 & 20 \\
\hline Sweden & 38.7 & 44.2 & 45.3 & 48.2 & 47.2 & 48.7 & 51.1 & 52.0 & 52.5 & 53.9 & 49 \\
\hline United Kingdom & 1.1 & 1.8 & 2.7 & 3.3 & 3.7 & 4.2 & 4.6 & 5.7 & 7.1 & 8.2 & 15 \\
\hline
\end{tabular}

Table 2. The power of RES installations in Poland [Energy Regulatory Office 2017]

\begin{tabular}{|l|c|c|c|c|c|c|c|c|}
\hline \multirow{2}{*}{\multicolumn{1}{c|}{ Type of RES }} & \multicolumn{7}{c|}{ Installed power [MW] } \\
\cline { 2 - 9 } & 2010 & 2011 & 2012 & 2013 & 2014 & 2015 & 2016 & 2017 \\
\hline Biogas plants & 82.884 & 103.487 & 131.247 & 162.241 & 188.549 & 212.497 & 233.967 & 235.373 \\
\hline Biomass power stations & 356.190 & 409.680 & 820.700 & 986.873 & $1,008.245$ & $1,122.670$ & $1,281.065$ & $1,362.030$ \\
\hline Solar power stations & 0.033 & 1.125 & 1.290 & 1.901 & 21.004 & 71.031 & 99.098 & 103.896 \\
\hline Wind power stations & $1,180.272$ & $1,616.361$ & $2,496.748$ & $3,389.541$ & $3,833.832$ & $4,582.036$ & $5,807.416$ & $5,848.671$ \\
\hline $\begin{array}{l}\text { Hydroelectric power } \\
\text { station }\end{array}$ & 937.044 & 951.390 & 966.103 & 970.128 & 977.007 & 981.799 & 993.995 & 988.377 \\
\hline AMOUNT & $2,556.423$ & $3,082.043$ & $4,416.088$ & $5,510.684$ & $6,028.637$ & $6,970.033$ & $8,415.541$ & $8,538.347$ \\
\hline
\end{tabular}

power plants (about $87.72 \mathrm{MW}$ ). However, it is worth noting that photovoltaic panels are mainly assembled as small domestic installations (prosumer). It can be assumed that in the near future there will be a dynamic development of this type of renewable energy installations due to the decreasing prices and increase in the efficiency of photovoltaic modules [Borenstain 2015, Griffin et al. 2013]. It is also worth mentioning that every year, the number of installations that rely on RES is growing in Poland, and the highest increase was observed in 2016 (by approx. 1,445 MW). This is primarily due to the amendment to the Act on renewable energy sources introduced in June 22, 2016, which defined the direction of financial development of RES market in Poland (introduction 
of the auction system) and concluded a period of uncertainty on the Polish RES market.

\section{Financing of RES in Poland}

Since October 10, 2005, the financing of renewable energy sources in Poland is based on the Tradable Green Certificates system (TGCs). As a consequence of the system, the producer of the energy obtained from wind, solar radiation, geothermal energy, waves, currents and tides and river falls, as well as from biomass gains property rights (the so-called Green Certificates) issued by the President of ERO. Each certificate corresponds to $1 \mathrm{MWh}$ of the electricity generated. The property rights are traded on the Polish Power Exchange, which contributes to large fluctuations in prices, resulting from the current economic situation on the RES market (Figure 2).

In the recent years, the price of green certificates has fallen dramatically. Such losses of value resulted from the lack of legal regulations and the uncertainties regarding the future of financing the renewable energy in Poland. Currently, the price of a green certificate is the lowest since the launch of the Polish Power Exchange with the weighted average price as of June (in 2017) was 24.38 PLN/MWh. This situation means that many installations that rely on RES in Poland are on the verge of bankruptcy [Wędzik et al. 2017].

The introduction of the Renewable Energy Sources Act in 2015 was to improve the Polish market situation by changing the supportive system for RES installations. The legislator proposed an auction system. Pursuant to the act, the government of the Republic of Poland is to decide on the amount of renewable energy to be procured, and then announce auctions (separately for instal- lations over 1 MWe and below 1 MWe), which will be won by the bidder who proposes the lowest price. The installations that win the auction are supported for 15 years. In addition, the RES Act introduced the concept of guaranteed feed-in-tariffs (FiT) for electricity producers having small, backyard installations, at guaranteed prices for a period of 15 years. The owners of the plants with a capacity of up to $3 \mathrm{~kW}$ were to receive a guarantee of energy sales at a price of approx. $0.75 \mathrm{PLN} / \mathrm{kWh}$, whereas the $3-10 \mathrm{~kW}$ range at a price up to $0.70 \mathrm{PLN} / \mathrm{kWh}$, depending on the RES technology. The number of micro-installations for which funding is provided was limited, and the tariff system was suspended after the total installed power capacity exceeded $800 \mathrm{MW}$.

However, on July 1, 2016, the last amendment to the AoRES in Poland came into force. This document introduced a new division of installations participating in auctions. These installations have been classified in the following groups:

1. installations using electric power in total, regardless of the source, greater than $3504 \mathrm{MWh} / \mathrm{MW} /$ year;

2. installations generating electrical energy partly from industrial and municipal waste of plant or animal origin, including the waste from waste treatment as well as water and wastewater treatment, in particular sewage sludge, in accordance with the provisions on waste in the scope of partial energy recovery from the thermal treatment of waste;

3. installations in which the $\mathrm{CO}_{2}$ emission does not exceed $100 \mathrm{~kg} / \mathrm{MWh}$, with a utilization rate of electric power installed higher than 3504 $\mathrm{MWh} / \mathrm{MW} /$ year;

4. members of the energy cluster;

5. members of the energy cooperative;

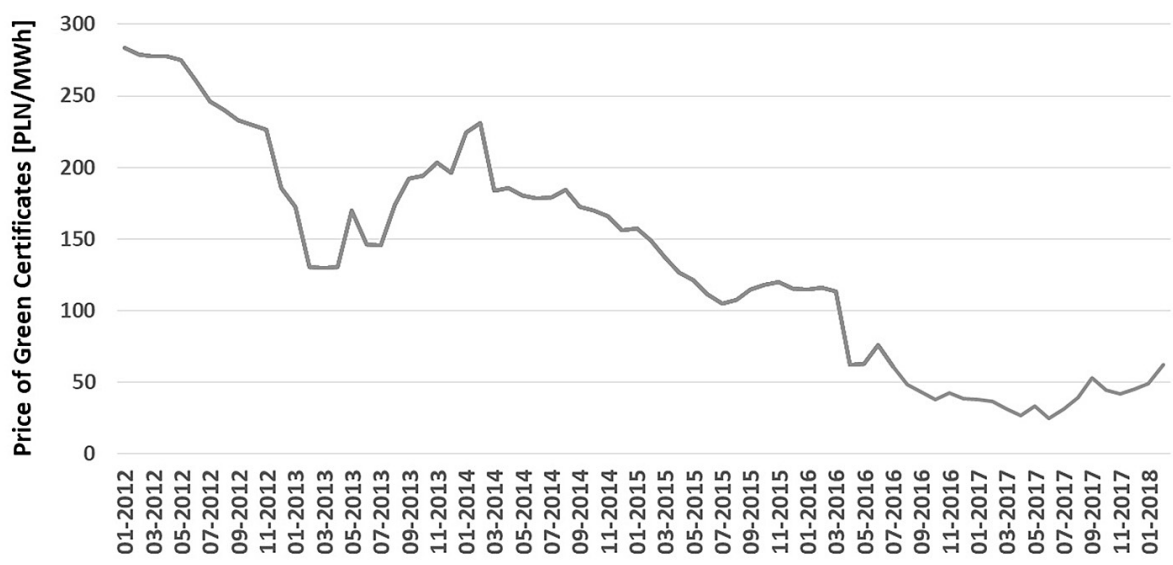

Fig. 2. Weighted average price of "green certificates" in 2012-2018 [Polish Power Exchange 2018] 
6. installations using only agricultural biogas for generating electricity;

7. other installations.

Moreover, according to the law in force, RES installation owners can decide themselves whether they want to stay in the old Tradable Green Certificate system, or if they want to use the new auction system. In order to improve the financial situation of agricultural biogas plants operating on the basis of the old system, the Polish government introduced the blue certificate (PMOZE_BIO). This instrument is granted to the installations that have agricultural status and is a solution that has definitely improved the situation on the biogas market in Poland (Figure 3).

In May 2017, the price of the blue certificate increased to over PLN 400/MWh (Figure 3), which contributed to the increased interest in biogas production in Poland. However, in June this price went down to $369.57 \mathrm{PLN} / \mathrm{MWh}$. In addition, the Polish government is working on another law amendment aimed at limiting the excessive increase in the price of certificates. Currently, there are 96 agricultural biogas plants operating in Poland, with a total installed power capacity of 101.093 MW [National Center for Agricultural Support 2018]. However, despite the introduction of a new renewable energy support system in Poland, the vast majority of investors remained in the old "green certificates" system.

\section{POTENTIALS OF HYDROGEN PRODUCTION IN POLAND}

The complicated situation in terms of supporting the financing of RES installations para- doxically contributed to the development of new technologies in Poland. On the basis of the growing interest in renewable energy sources and the support of the Polish government for development of innovative technologies in the field of energy production, the development of the hydrogen production and distribution market is also expected. Energy-rich and green gas fuel produced from organic waste can contribute to the diversification of energy sources and increase the energy security of the country [Kazimierowicz 2014, Wiater and Horysz 2017].

Thus far, numerous research results on hydrogen production in the DF process have been presented in the scientific literature. However, it should be noted that glucose or other simple sugars were used as a substrates in a large part of these studies [Calli et al. 2008, Collet et al. 2004, Ghosh and Hallenbeck 2009, Kumar and Das 2000, Mizuno et al. 2000, Schröder et al. 1994, Van Niel et al. 2002]. Unfortunately, at an industrial scale, the use of such substrates is economically unjustified; therefore, the research on hydrogen production from composite substrates has the greatest significance for industrial installations. Such substrates include the organic waste from agri-food industry characterized by high energetic potential (Table 3 ). It is worth highlighting that the recent years have seen increasing interest in multi-directional use of these materials [White et al. 2013, Czekala 2018]. This interest has been in a large part motivated by the aim of limiting storage of organic materials in landfill sites that leads to their uncontrolled decomposition. The data reported by the European Commission shows that in 2010, more than 89 million $\mathrm{Mg}$ of food waste were generated in Europe, out of which almost 35 million $\mathrm{Mg}$ constituted the waste

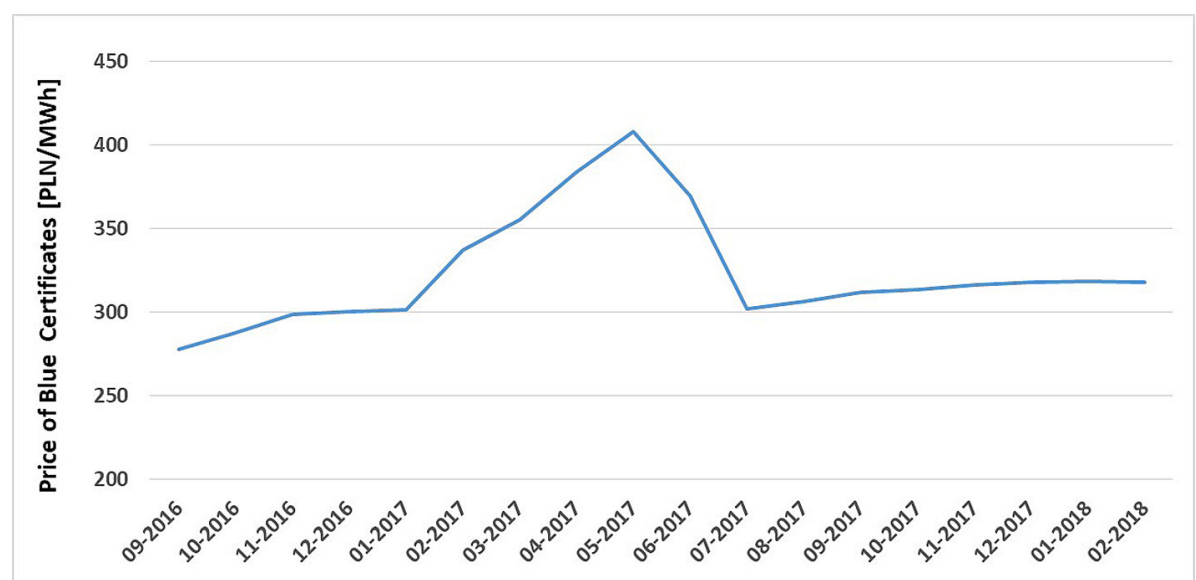

Fig. 3. Weighted average price of "blue certificates" in 2016-2018 [Polish Power Exchange 2018] 
Table 3. Biohydrogen production yields of DF of agricultural waste.

\begin{tabular}{|c|c|c|c|c|c|}
\hline Substrate & $\begin{array}{c}\text { Biohydrogen yield } \\
\text { (ml } \mathrm{H}_{2} / \mathrm{g} \text { VS) }\end{array}$ & $\begin{array}{c}\text { Reactor operation } \\
\text { mode }\end{array}$ & $\begin{array}{c}\text { Temperature } \\
\left({ }^{\circ} \mathrm{C}\right)\end{array}$ & Pretreatment & Reference \\
\hline Cattle manure & 65 & Batch & 52 & $90^{\circ} \mathrm{C}, 3 \mathrm{~h}$ & [Guo et al. 2010] \\
\hline Cattle wastewater & $53^{a}$ & Batch & 45 & - & [Tang et al. 2008] \\
\hline Cheese whey & $290^{\mathrm{a}}$ & CSTR & 35 & $\mathrm{NaHCO} 320 \mathrm{~g} / \mathrm{L}$ & $\begin{array}{l}\text { [Venetsaneas et al. } \\
\text { 2009] }\end{array}$ \\
\hline Chicken skin & 10 & Batch & 35 & - & [Zhu et al. 2009] \\
\hline Corn stover & $49^{a}$ & Batch & 35 & $220^{\circ} \mathrm{C} 3 \mathrm{~min}$ & [Datar et al. 2007] \\
\hline Corn stover & $66^{\mathrm{a}}$ & Batch & 35 & $\begin{array}{c}1.2 \% \mathrm{HCl}+200{ }^{\circ} \mathrm{C} \\
1 \mathrm{~min}\end{array}$ & [Datar et al. 2007] \\
\hline Corn straw & 9 & Batch & 35 & - & [Li and Chen 2007] \\
\hline Corn straw & $68^{a}$ & Batch & 35 & $1.5 \mathrm{MPa} 10 \mathrm{~min}$ & [Li and Chen 2007] \\
\hline Cornstalk & 3 & Batch & 36 & - & [Zhang et al. 2007] \\
\hline Cornstalk & 57 & Batch & 36 & $0.5 \% \mathrm{NaOH}$ & [Zhang et al. 2007] \\
\hline Cornstalk & 150 & Batch & 36 & $\begin{array}{c}0.2 \% \mathrm{HCl} \text { boiled } \\
30 \mathrm{~min}\end{array}$ & [Zhang et al. 2007] \\
\hline Cow feces and urine & $18^{a}$ & Batch & 75 & - & $\begin{array}{c}\text { [Yokoyama et al. } \\
\text { 2007] }\end{array}$ \\
\hline Cow feces and urine & $29^{a}$ & Batch & 60 & - & $\begin{array}{c}\text { [Yokoyama et al. } \\
\text { 2007] }\end{array}$ \\
\hline Cow feces and urine & $0.7^{\mathrm{a}}$ & Batch & 37 & - & $\begin{array}{c}\text { [Yokoyama et al. } \\
2007]\end{array}$ \\
\hline Dairy manure & 18 & Batch & 36 & $\begin{array}{c}0.2 \% \mathrm{HCl} \text { boiled } \\
30 \mathrm{~min}\end{array}$ & [Xing et al. 2010] \\
\hline Dairy manure & 14 & Batch & 36 & $\begin{array}{l}0.2 \% \mathrm{NaOH} \text { boiled } \\
30 \mathrm{~min}\end{array}$ & [Xing et al. 2010] \\
\hline Dairy manure & 14 & Batch & 36 & $\begin{array}{l}\text { Infrared radiation } \\
\qquad 2 \mathrm{~h}\end{array}$ & [Xing et al. 2010] \\
\hline Dairy solid cow waste & 97 & Batch & 35 & $\begin{array}{l}2.5 \% \text { oxalic acid, } \\
50 \mathrm{~g} / \mathrm{L} \text { dairy cow } \\
\text { solid waste and } \\
\text { boiled } 30 \mathrm{~min}\end{array}$ & [Chu and Wang 2017] \\
\hline Food waste & 196 & Batch & 36 & $160^{\circ} \mathrm{C} 2 \mathrm{~h}$ & [Li et al. 2008] \\
\hline Food waste & $60 a$ & Batch & 35 & n.d. & [Kim et al. 2004] \\
\hline Food waste & 77 & Batch & 35 & - & [Lay et al. 2005] \\
\hline Food waste & $125^{a}$ & CSTR & 35 & - & [Shin and Youn 2005] \\
\hline Food waste & 65 & $\begin{array}{l}\text { Semi-continuous } \\
\text { rotating drum }\end{array}$ & 40 & - & $\begin{array}{l}\text { [Wang and Zhao } \\
\text { 2009] }\end{array}$ \\
\hline Food waste & 13 & CSTR & 20 & - & [Karlsson et al. 2008] \\
\hline Food waste & 3 & CSTR & 37 & - & [Karlsson et al. 2008] \\
\hline Grass silage & 6 & Batch & 35 & - & [Karlsson et al. 2008] \\
\hline Grass silage & 16 & Batch & 70 & - & [Karlsson et al. 2008] \\
\hline Maize leaves & 18 & Batch & 70 & - & [Ivanova et al. 2009] \\
\hline Maize leaves & 42 & Batch & 70 & $130^{\circ} \mathrm{C} 30 \mathrm{~min}$ & [Ivanova et al. 2009] \\
\hline Pig slurry & 4 & CSTR & 70 & - & [Kotsopoulos 2009] \\
\hline Swine liquid manure & $209^{a}$ & $\begin{array}{l}\text { Semi-continuously- } \\
\text { fed fermeter }\end{array}$ & 35 & - & [Xing et al. 2010] \\
\hline Wheat straw & 1 & Batch & 36 & - & [Fan et al. 2006] \\
\hline Wheat straw & 68 & Batch & 36 & $\begin{array}{c}\mathrm{HCl} 2 \%+ \\
\text { microwave heating }\end{array}$ & [Fan et al. 2006] \\
\hline Wheat straw & $49^{a}$ & Batch & 70 & $130^{\circ} \mathrm{C} 30 \mathrm{~min}$ & [lvanova et al. 2009] \\
\hline
\end{tabular}

${ }^{\mathrm{a}}$ Calculated from literature data

from the manufacturing sector [European Commission 2010]. Large amounts of organic waste are also produced in Poland, including about 6.5 million $\mathrm{Mg}$ of waste from food production, 2 million $\mathrm{Mg}$ of waste from household, 90 million $\mathrm{Mg}$ of manure and slurry, and more than 10 million $\mathrm{Mg}$ of waste straw produced each year. These materials can be applied for the production of ecological gas fuels - methane and biohydrogen. The agri-food sector generates three distinguishable 
types of waste: the wastes generated from direct agricultural production and post-harvest residues, animal production wastes (manure and slurry) and food waste [Guo et al. 2010].

\section{Slurry and manure}

Slurry, a mixture of animal feces and urine (mostly cattle or swine) and water from washing positions and watering, is one of the most common biogas substrates in Europe and Poland [Dach et al. 2014, Dach et al. 2016]. It is a side-product of non-bedding animal husbandry systems. Slurry is a natural fertilizer with a high content of nutrients in the forms that are easily available to plants. Its composition depends primarily on the degree of dilution with water, but also on the type of animals, age and the method of feeding. According to the available data, this material has $\mathrm{N}_{\text {total }}$ content of $1363 \mathrm{mg} / \mathrm{L}, \mathrm{P}_{\text {total }}$ content of $255 \mathrm{mg} / \mathrm{L}$ and COD of 47,820 $\mathrm{mg} \mathrm{O}_{2} / \mathrm{L}$ [Marszałek et al. 2014].

According to the data provided by the National Center for Agricultural Support (NCAS) [2017], approximately 598,807 and 774,997 $\mathrm{Mg}$ this material were used for $\mathrm{AD}$, in 2015 and 2016, respectively. In the biogas plants built at cattle and swine farm, slurry is suitable for diluting solid substrates (consisting mainly of plant materials). The biogas yields of cattle and swine slurry are approximately $210 \mathrm{~m}^{3} / \mathrm{Mg} \mathrm{VS}$ and 250 $\mathrm{m}^{3} / \mathrm{Mg}$ VS, respectively [KTBL 2009]. The results of research carried out by Yokoyama et al. [2007] and Kotsopoulos [2009] showed that these materials can also be considered as substrates for hydrogen fermentation.

Manure is another type of natural fertilizer used in $\mathrm{AD}$. This material is a mixture of animal droppings with straw. As in the case of slurry, it is characterized by high fertilizing value. Its chemical composition depends primarily on the amount of spent litter and the species of animals, their way of feeding and health. This material can also serve as a substrate for the production of biohydrogen.

The study of Guo et al. [2010] showed that cattle manure allows obtaining maximum hydrogen efficiency at a level of $65 \mathrm{ml} / \mathrm{g}$ VS. However, its utilization for energy purposes in Poland is limited to the production of biogas and biomethane. In 2016, $86144.669 \mathrm{Mg}$ of this material were used in Polish agricultural biogas plants [National Center for Agricultural Support 2017].
It should also be added that animal droppings, and especially manure of pigs and poultry, are characterized by high nitrogen content [Angelidaki and Ahring 1994, Hansen et al. 1998], which can inhibit the fermentation process and hydrogen production [Hobson et al. 1974]. This makes using these substrates in mono-fermentation difficult [Fatina et al. 1988, Van Velsen 1979]. Using co-fermentation with lignocellulosic materials in the batch mixture can be a solution to this problem as it enables to obtain a suitable $\mathrm{C} / \mathrm{N}$ ratio [Neshat et al. 2017].

\section{Food waste}

Production of large amount of food waste is one of the most important problems of the modern world (including in Poland). Scientific research shows that between $1 / 3$ and $1 / 2$ of the food produced worldwide is not consumed [Gustavsson et al. 2011]. This results in negative effects on the entire food supply chain. In addition, improper management of this type of waste may contribute to the deterioration of the natural environment. In Poland, over 47 million $\mathrm{Mg}$ of food are produced yearly, which makes approx. $172 \mathrm{~kg}$ of food per capita yearly. However, it should kept in mind that about $14 \%$ of food is already wasted during the production phase [European Commission 2010]. Due to high heterogeneity, high water content and low calorific value, the use of food waste for direct energy production through combustion is difficult. Biological processing, such as fermentation and composting, were proposed as suitable means of the management of these materials [Cerda et al. 2018, Yasin et al., 2013]. The studies carried out so far have shown that food waste can have a dry matter content of 10 to $26 \%$ and a $\mathrm{C} / \mathrm{N}$ ratio in the range of $14.7-36.4$ [Thi et al. 2015]. However, it should be remembered that the manner of its collection and storage can significantly affect the content of inorganic and organic matter, which can reduce the efficiency of biological processes.

The production of biohydrogen, undergoing development for the last 15 years, can serve as an innovative method of biological processing. Numerous tests aimed at determining the efficiency of hydrogen generation from food waste have been carried out [Chu et al. 2012, Danko et al. 2008, De Gioannis et al. 2017, Yun et al. 2018]. The results show high hydrogen production potential that largely depends on the type of pre-treatment 
of the inoculum [Yasin et al. 2013]. A large potential for biohydrogen production from food wastes can also be anticipated in Poland. Residues of fruits and vegetables are currently one of the most commonly used batch material by Polish investors in biogas plants. In 2016, 665,338.208 Mg of such substrates were used in Polish biogas plants, which accounted for approx. $20 \%$ of all materials used in the fermentation process. Specifically, $28,596.802 \mathrm{Mg}$ of waste from food processing, $25,962.931$ of residues from processing of fruits and vegetables, and $2,851.251 \mathrm{Mg}$ of restaurant waste were utilized for AD in 2016 [National Center for Agricultural Support 2017]

\section{Dairy industry waste}

The waste from the dairy industry is another type of waste that significantly affects the environmental pollution. Production in dairy plants results in several types of technological waste and leachates, both in liquid and solid forms. Whey, a by-product of cheese production, is one of the most dangerous dairy wastes. It contains approx. $600 \mathrm{mg} \mathrm{N} / \mathrm{L}$, and its COD and $\mathrm{BOD}_{5}$ levels are 27-60 g/L and 50-102 g/L, respectively [Carvalho et al. 2013]. Two types of whey are formed as a result of precipitation of casein in the production process - acid and sweet whey. The acid whey $(\mathrm{pH}$ $<5$ ) is produced after the fermentation process or after the addition of organic or mineral acids. ON the other hand, the sweet whey $(\mathrm{pH}=6-7)$ is obtained as a result of the addition of proteolytic enzymes [Carvalho et al. 2013, Panesar et al. 2007]. The dry matter of whey obtained from cow milk contains about $70-80 \%$ of lactose, about $9 \%$ of proteins and about $8-20 \%$ of minerals and other trace components [Daufin et al. 1998].

The second type of liquid waste in dairy plants is buttermilk. However, it may be a used in the production of food buttermilk, which is why it is not considered a pollutant. Moreover, technological wastewater is generated during dairy production, containing high loads of organic matter. The most common way of its treatment utilizes traditional wastewater treatment plants that use activated sludge or sequencing batch reactors (SBR) [Wichern et al. 2008, Wu et al. 2008]. Such treatment results in the formation of sediments. The wastes from the dairy industry do not contain dangerous substances or heavy metals but are characterized by high organic load, which can reach approx. $15 \mathrm{~g} / \mathrm{L}$ COD [Carvalho et al. 2013,
González Siso 1996]. This creates difficulties for typical wastewater treatment plants. Therefore, AD [Mata-Alvarez et al. 2000, Naik et al. 2010, Saxena and Adhikari 2009, Ward et al. 2008] or DF [Ghimire et al. 2015] may be the most appropriate means of their safe utilization.

The data of NCAS shows that in 2015, approximately $47,817.242 \mathrm{Mg}$ of waste from the dairy industry were supplied to the Polish agricultural biogas plants. In 2016, the amount increased to $89.1414 .969 \mathrm{Mg}$ as a result of the development of the renewable energy sector. The popularity of dairy wastes in biogas generation is also a consequence of the high yields obtained using this substrate (253.85 $\mathrm{Nm}^{3} \mathrm{CH}_{4} / \mathrm{Mg}$ VS for whey) [Kozłowski et al. 2016]. The waste from dairy industry can be used in the production of biohydrogen. Venetsaneas et al. [2009] reported obtaining about $290 \mathrm{ml} \mathrm{H}_{2} / \mathrm{g}$ VS in DF.

\section{Maize silage}

Maize silage, while not classified as a waste of agricultural industry, has become a staple in fermentation. It is one of the most commonly used substrates in biogas plants in Central and Eastern Europe [Dach et al. 2014, Hermann et al. 2015]. Its popularity is a result of high yield of biogas and methane reaching approximately 6050 - $6750 \mathrm{~m}^{3} / \mathrm{ha}$ [Piwowar et al. 2016]. Moreover, monofermentation of this substrate does not pose serious problems at the industrial scale. High demand for maize silage as biogas substrate is reflected in data. In 2016, the maize silage usage in biogas production amounted to $439,135.422 \mathrm{Mg}$ in Poland. In Germany, this substrate constitutes $70 \%$ of all substrates used for energy generation [Multerer 2014]. The demand for corn silage has also driven an increase in its price, which is 25-35 Euro/Mg.

Corn silage is a substrate that does not require complicated treatment prior to storage, which is an additional advantage. It is common to ferment corn in bunker silos covered with plastic foil in order to reduce the oxygen supply. Following silaging (after approximately 4-6 weeks) the substrate can be directly fed into a biogas installation [Murphy et al. 2011]. During silaging under anoxic conditions, lactic acid bacteria convert carbohydrates into lactic acid which serves as a natural preservative. Besides lactic acid, acetic acid and other volatile fatty acids (propionic, formic, caproic, valeric) 
and alcohols (ethanol, methanol, propanol) are formed. Care should be taken to avoid excessive oxygen diffusion, as it may result in formation of butyric acid which negatively impacts methane fermentation [Hermann et al. 2015]

The data obtained from studies in continuous system indicates that corn silage fermentation yields $53.8 \mathrm{Nl} \mathrm{H}_{2} / \mathrm{VS}$ [Benito Martin et al. 2017]. However, application of this substrate to DF , may pose problems because of significant content of lignin and cellulose.

\section{BIOHYDROGEN PRODUCTION IN DARK FERMENTATION PROCESS}

During DF, metabolic pathways, known well form the studies on methane fermentation and hydrogenase enzyme, are utilized. First, glucose is metabolized to pyruvate (Eq. (1)) which is then oxidized in the second step to acetyl coenzyme A with simultaneous reduction of ferrodoxin $(\mathrm{Fd})$ (Eq. (2)). In the third step, ferrodoxin undergoes oxidation catalyzed by hydrogenase with the resulting release of molecular hydrogen (Eq. (3)) [Adams and Stiefel 1998].

$$
\begin{gathered}
\text { glucose } \rightarrow \text { pyruvate } \\
\text { pyruvate }+\mathrm{CoA}+2 \mathrm{Fd}(\text { ox }) \rightarrow \\
\rightarrow \text { acetyl }-\mathrm{CoA}+2 \mathrm{Fd}(\text { red })+\mathrm{CO}_{2} \\
2 \mathrm{Fd}(\mathrm{red}) \rightarrow 2 \mathrm{Fd}(\mathrm{ox})+\mathrm{H}_{2}
\end{gathered}
$$

Carbohydrates, proteins and fats are transformed into volatile fatty acids. Theoretically, one mole of glucose yields 4 moles of molecular hydrogen, 2 moles of carbon dioxide and two moles of acetate (Eq. (4)).

$$
\begin{gathered}
\mathrm{C}_{6} \mathrm{H}_{12} \mathrm{O}_{6}+2 \mathrm{H}_{2} \mathrm{O} \rightarrow 4 \mathrm{H}_{2}+ \\
+2 \mathrm{CO}_{2}+2 \mathrm{CH}_{3} \mathrm{COOH}
\end{gathered}
$$

In reality, however, the obtained yields range between 1 to 2.7 moles of molecular hydrogen that form 1 mole of glucose (Eq. (5)) [De Gioan- nis et al. 2017]. The deviation from the theoretical yield is a result of production of butyrate.

$$
\begin{gathered}
\mathrm{C}_{6} \mathrm{H}_{12} \mathrm{O}_{6}+2 \mathrm{H}_{2} \mathrm{O} \rightarrow 2 \mathrm{H}_{2}+2 \mathrm{CO}_{2}+ \\
+\mathrm{CH}_{3} \mathrm{CH}_{2} \mathrm{CH}_{2} \mathrm{COOH}
\end{gathered}
$$

Because of the partly shared metabolic pathways between methane and hydrogen production, a high yield hydrogen production process demands inhibition of acetogenesis and methanogenesis (Fig. 4) [Adams and Stiefel 1998]. Initial heat treatment of the culture may be applied to stop methanogens $\left(80-104^{\circ} \mathrm{C}\right.$ for $\left.15-120 \mathrm{~min}\right)$ [Kraemer and Bagley 2007, Nath and Das 2003]. Methanogenic bacteria, unable to form spores, do not survive extreme temperatures, as opposed to the sporulating hydrogen producers. Applying short hydraulic retention times (HRT) and treatment of the substrate with acid are other effective methods of inhibiting methanogenesis and increasing hydrogen yield [Guo et al. 2010].

Production of hydrogen during DF is also dependent on the type of substrate, its concentration in the bioreactor and the microorganisms introduced with the inoculums. The research data indicates that utilizing mixed cultures from natural sources (e.g. compost, anaerobic fermentation) yields the best results. It is also possible to utilize non-sterilized substrates because of such approach [Hawkes et al. 2002].

\section{ENVIRONMENTAL PARAMETERS OF DARK FERMENTATION}

\section{Temperature}

Hydrogen generation during fermentation is dependent on temperature, among other factors. According to the van't Hoff equation, the rate of a chemical reaction increases along with the temperature. Fermentation, however, is catalyzed by the microorganisms that are prone to activity loss at temperatures that deviate from their optimum. Most studies on biohydrogen fermentation have been conducted at mesophilic temperatures $\left(30-40^{\circ} \mathrm{C}\right)$ [Wang and Zhao 2009, Dong et al. 2009, Hong and Haiyun 2010, Lee and Chung 2010, Zong et al. 2009]. The results showed increasing hydrogen production up to $40^{\circ} \mathrm{C}$ and inhibition of the process at $45^{\circ} \mathrm{C}$ [Kim et al. 2008]. 


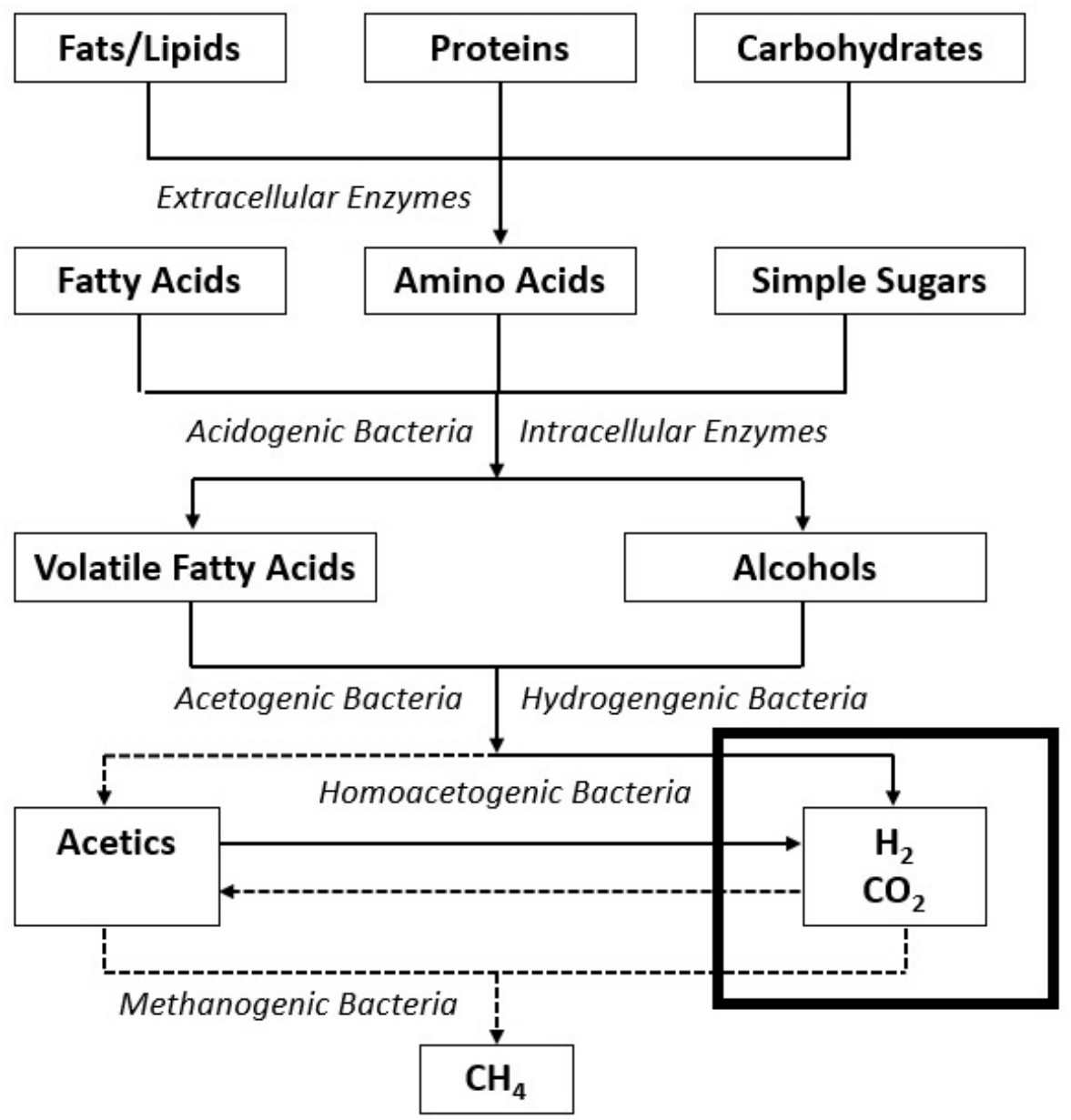

Fig. 4. Scheme of AD [Mao et al. 2015].

DF under thermophilic conditions has also been investigated. Elevated temperature resulted in the increased enzymatic activity (hydrogenases) and inhibition of microorganisms responsible for lactic acid formation [Lay et al. 1999, Oh et al. 2004, Valdez-Vazquez et al. 2005].

\section{$\mathrm{pH}$}

Maintenance of proper $\mathrm{pH}$ value throughout the process of DF is crucial for obtaining hydrogen with a high yield. This parameter influences the hydrogenase activity which is responsible for the oxidation of ferredoxin with the release of molecular hydrogen. The research data indicates that low $\mathrm{pH}$ values may lead to the inhibition of this enzyme [Khanal et al. 2004, Nazlina et al. 2011].

The balance between metabolic pathways is modulated by $\mathrm{pH}$ which leads to different profiles of formed metabolites. At $\mathrm{pH}$ in the range of 4.5-6.0, mostly acetate and butyrate are released, at neutral and basic $\mathrm{pH}$ values, the generation of ethanol and propionate predominates [Guo et al.
2010]. Suppression of methanogenesis is an important effect of decreased $\mathrm{pH}$.

The optimum $\mathrm{pH}$ for hydrogen fermentation is dependent mainly on the substrate used. The $\mathrm{pH}$ of 5.5 is optimal for the wastes generated during food processing [Shin and Youn 2005]. Substrates of a more complex nature (corn or wheat straw for example) showed better hydrogen yields when fermented at $\mathrm{pH}$ of 7.0-7.5 [ $\mathrm{Li}$ and Chen 2007, Karlsson et al. 2008, Fan et al. 2006]. The optimum $\mathrm{pH}$ values for fermentation of various agricultural and industrial wastes with mixed bacterial cultures are summarized in Table 4.

\section{Biohydrogen partial pressure}

Maintaining low partial pressure of hydrogen in the bioreactor is crucial in order to achieve high effectiveness of the hydrogen production process in DF. Awareness of the influence of temperature on this parameter is important [Levin et al. 2004]. There are a few approaches that allow to limit the concentration of dissolved hydrogen. The data obtained thus far, indicated that increasing the 
Table 4. Optimal value of $\mathrm{pH}$ in DF for different substrates

\begin{tabular}{|l|c|c|c|}
\hline Substrates & $\mathrm{pH}$ range & $\begin{array}{c}\text { Optimal } \\
\mathrm{pH}\end{array}$ & Reference \\
\hline Food waste & $5.0-6.0$ & 5.5 & $\begin{array}{c}\text { [Shin and } \\
\text { Youn 2005] }\end{array}$ \\
\hline Grass silage & $4.0 ; 5.0 ; 6.0$ & 6.0 & $\begin{array}{c}\text { [Karlsson et } \\
\text { al. 2008] }\end{array}$ \\
\hline Maize straw & $4.0-8.0$ & $7.0-7.5$ & $\begin{array}{c}\text { [Li and Chen } \\
\text { 2007] }\end{array}$ \\
\hline Wheat straw & $4.0-9.0$ & 7.0 & $\begin{array}{c}\text { [Fan et al. } \\
2006]\end{array}$ \\
\hline
\end{tabular}

rate of the stirrer in the fermentation tank may serve as the simplest method [Chou et al. 2008]. Sparging with different gas (nitrogen, argon, carbon dioxide or methane) may help remove the dissolved hydrogen. Introduction of sparging, however, results in dilution of hydrogen in the produced biogas and, what is even more important, its application at industrial scale would have a negative impact on the financial balance of the plant. Application of membrane techniques for limiting hydrogen partial pressure in the tank has also been proposed [Liang et al. 2002, Nielsen et al. 2001, Toplyakov et al. 2002].

\section{CURRENT STATE, LIMITATIONS AND FUTURE RESEARCH}

Currently, identification of economical substrates for future implementation in industrialscale DF processes is one of the most important tasks. The biomass obtained, for example, from the first stages of photofermentation, energetic plants or organic waste from industry may be used for fermentative processes. These may be considered interesting substrates for biohydrogen production, yet their application still requires research. It should be pointed out that the suitability of various substrates for biohydrogen production is difficult to assess because studies show different yields even for the same type of feed. It is a result of applying different microorganisms and the variability of the substrates themselves, and the effect of these factors on the metabolic pathways that are active during fermentation that in turn affect the hydrogen production [Monlau et al. 2013]. Moreover, the conditions under which various studies are conducted differ significantly, as there are no standard methods concerning substrate pretreatment and fermentation parameters.
Significant progress has been made towards understanding the biochemistry of biohydrogen generation, including molecular and biochemical characterization of the enzymes involved, description of pathways responsible for supply of reducing equivalents and physiology of various microorganisms known to produce $\mathrm{H}_{2}$ [Hallenbeck 2001]. Moreover, genetic manipulation shows a potential to improve the process through redirection of the flow of electrons in the microbial metabolism towards hydrogen generation [Keasling et al. 1998]

All the aspects mentioned above concern the hydrogen generation from any substrate, and should be taken into account in research plans concentrated on the bioconversion of residual agricultural or processing biomass to biohydrogen in $\mathrm{DF}$.

\section{CONCLUSIONS}

The DF process can be utilized for the production of high-energy and green gas fuel (hydrogen) on an industrial scale all over the world. The substrates used in the described process may come from the agro-food waste, which would significantly reduce their uncontrolled decomposition in the environment. Food waste, straw, grass silage are a materials characterized by a high potential for hydrogen production. However, it should be remembered that the gas production efficiency is significantly affected by the composition of the substrate added to the fermentation reactor. Moreover, special attention should be paid to the basic environmental parameters (including temperature, $\mathrm{pH}$ and hydrogen molecular pressure) which ought to be controlled and regulated at appropriate levels in order to enable efficient and effective fuel production. However, the impact of many factors on the hydrogen fermentation process is still unknown. Therefore, further research on biohydrogen production is necessary.

\section{REFERENCES}

1. Act of 10 June 2016 amending the Renewable Energy Sources Act and certain other acts, http://dziennikustaw.gov.pl/du/2016/925/1; 2016 [accessed 06 March 2018].

2. Adams M.W.W., Stiefel E.I., 1998. Biological hydrogen production: not so elementary. Science, 282, 1842-1843. 
3. Alves H.J., Bley Junior C., Niklevicz R.R., Frigo E.P., Frigo M.S., Coimbra-Araújo C.H., 2013. Overview of hydrogen production technologies from biogas and the applications in fuel cells. Int $\mathrm{J}$ Hydrogen Energy, 38,5215-5225.

4. Angelidaki I., Ahring B., 1994. Anaerobic thermophilic digestion of manure at different ammonia loads: effect of temperature. Water Res, 28, 727-731.

5. Balat M., 2008. Potential importance of hydrogen as a future solution to environmental and transportation problems. Int $\mathrm{J}$ Hydrogen Energy 33,4013-4029.

6. Benito Martin P.C., Schlienz M., Greger M., 2017. Production of bio-hydrogen and methane during semi-continuous digestion of maize silage in a two-stage system, International Journal of Hydrogen Energy, 42, 5768-5779.

7. Borenstein S., 2015. Is the Future of Electricity Generation really Distributed? Energy Inst. Haas. https://energyathaas.wordpress.com/2015/05/04/ is-the-future-of-electricity-generation-really-distributed, [accessed 1 February 2018].

8. Budzianowski WM., 2011. Can 'negative net CO2 emissions' from decarbonised biogas-to-electricity contribute to solving Poland's carbon capture and sequestration dilemmas? Energy, 36, 6318-6325.

9. Calli B., Schoenmaekers K., Vanbroekhoven K., Diels L., 2008. Dark fermentative H2 production from xylose and lactose - Effects of on-line $\mathrm{pH}$ control. International Journal of Hydrogen Energy, $33,522-530$.

10. Carvalho F., Prazeres A.R., Rivas J., 2013. Cheese whey wastewater: Characterization and treatment. Science of The Total Environment, 445-446, 385-396.

11. Cerda A., Artola A., Font X., Barrena R., Gea T., Sánchez A., 2018. Composting of food wastes: Status and challenges. Bioresource Technology, 248, 57-67.

12. Chou C., Wang C., Huang C., Lay J., 2008. Pilot study of the influence of stirring and $\mathrm{pH}$ on anaerobes converting high-solid organic wastes to hydrogen. Int J Hydrogen Energy, 33, 1550-1558.

13. Chu C.F., Xu K.Q., Li Y.Y., Inamori Y., 2012. Hydrogen and methane potential based on the nature of food waste materials in a two-stage thermophilic fermentation process. International Journal of Hydrogen Energy, 37, 10611-10618.

14. Chu C.Y., Wang Z.F., 2017. Dairy cow solid waste hydrolysis and hydrogen/methane productions by anaerobic digestion technology. International Journal of Hydrogen Energy, 42, 30591-30598.

15. Collet C., Adler N., Schwitzguebel J.P., 2004. Hydrogen production by Clostridium thermacolactium during countinuous fermentation of lactose. Int. J. of Hydrogen Energy, 29, 1479-1485.

16. Czekala W., 2018. Agricultural Biogas Plants as a Chance for the Development of the Agri-Food
Sector. Journal of Ecological Engineering, 19, 2, 179-183.

17. Dach J., Boniecki P., Przybył J., Janczak D., Lewicki A., Czekała W., Witaszek K., Rodriguez Carmona P.C., Cieślik M., 2014. Energetic efficiency analysis of the agricultural biogas plant in $250 \mathrm{~kW}(\mathrm{e})$ experimental installation. Energy, 69, 34-38.

18. Dach J., Koszela K., Boniecki P., Zaborowicz M., Lewicki A., Czekała W., Skwarcz J., Wei Qiao, Piekarska-Boniecka H., Białobrzewski I., 2016. The use of neural modelling to estimate the methane production from slurry fermentation processes. Renewable and Sustainable Energy Reviews, 56, 603-610.

19. Danko A.S., Pinheiro F., Abreu A.A., Alves M.M., 2008. Effect of methanogenic inhibitors, inocula type, and temperature on biohydrogen production from food components. Environ. Eng. Manage. J., 7, 531-536.

20. Datar R., Huang J., Maness P.C., Mohagheghi A., Czernik S., Chornet E., 2007. Hydrogen production from the fermentation of corn stover biomass pretreated with a steam-explosion process. Int $\mathrm{J}$ Hydrogen Energy, 32, 932-939.

21. Daufin G., René F., Aimar P., 1998. Les separations par membrane dans les procédés de l'industrie alimentaire, Collection Sciences et Techniques Agroalimentaires, Paris, France.

22. De Gioannis G., Muntoni A., Polettini A., Pomi R., Spiga D., 2017. Energy recovery from one- and two-stage anaerobic digestion of food waste. Waste Management, 68, 595-602.

23. Dong L., Zhenhong Y., Yongming S., Xiaoying K., $\mathrm{Yu}$ Z., 2009. Hydrogen production characteristics of the organic fraction of municipal solid wastes by anaerobic mixedculture fermentation. Int. J. Hydrogen Energy, 34, 812-820.

24. Energy Regulatory Office, 2017. The power of RES installations in Poland in 30 September 2017, https://www.ure.gov.pl/pl/rynki-energii/energiaelektryczna/odnawialne-zrodla-ener/potencjalkrajowy-oze/5753,Moc-zainstalowana-MW.html; 2017 [accessed 06 March 2018].

25. European Commision (DG ENV), Directorate C - Industry 2010. 2010. Preparatory study on food waste across EU 27, https:// ec.europa.eu/food/safety/food_waste/library_en; [accessed 06 March 2018].

26. Eurostat Statistics Explained, 2017. Energy from renewable sources, http://ec.europa.eu/eurostat/ statistics-explained/index.php/Energy_from_renewable_sources; [accessed 05 March 2018].

27. Fan Y., Zhang Y., Zhang S., Hou H., Ren B., 2006. Efficient conversion of wheat straw wastes into biohydrogen gas by cow dung compost. Bioresour Technol, 97, 500-505.

28. Farina R., Boopathy R., Hartmann A., Tilche A., 
1988. Ammonia stress during thermophilic digestion of raw laying hen wastes. In Proceedings of the Fifth International symposium on anaerobic digestion, 111-117.

29. Ghimire A., Frunzo L., Pirozzi F., Trably E., Escudie R., Lens P.N.L., Esposito G., 2015. A review on dark fermentative biohydrogen production from organic biomass: Process parameters and use of by-products. Applied Energy, 144:73-95.

30. Ghosh D., Hallenbeck P.C., 2009. Fermentative hydrogen yields from different sugars by batch cultures of metabolically engineered Escherichia coli DJT135. Int J Hydrogen Energy, 34, 7979-7982.

31. González Siso M.I., 1996. The biotechnological utilization of cheese whey: A review. Bioresour. Technol., 57(1), 1-11.

32. Griffin B., Buisson P., Criqui P., Mima S., 2013. White knights: will wind and solar come to the rescue of a looming capacity gap from nuclear phase-out or slow CCS start-up? Clim. Chang., $123,623-635$.

33. Guo X.M., Trably E., Latrille E., Carrère H., Steyer J.P., 2010. Hydrogen production from agricultural waste by dark fermentation: A review. International Journal of Hydrogen Energy, 35, 10660-10673.

34. Gustavsson J., Cederberg C., Sonesson U., van Otterdijk R., Meybeck A., 2011. Global Food Losses and Food Waste: Extent, Causes and Prevention. Rome: Food and, Agriculture Organisation of the United Nations.

35. Hallenbeck P.C., 2001. Integration of hydrogen evolving systems with cellular metabolism: the molecular biology and biochemistry of electron transport factors and associated reductases. In: J. Miyake T, Matsunaga, A. San Pietro (Eds.), Biohydrogen II, Pergamon, Elsevier Sciences, Amsterdam; 171-184.

36. Hansen K.H., Angelidaki I., Ahring B.R., 1998. Anaerobic digestion of swine manure: inhibition by ammonia. Water Research, 32, 5-12.

37. Hassen Sellami M., Loudiyi K., 2017. Electrolytes behavior during hydrogen production by solar energy. Renewable and Sustainable Energy Reviews, 70:1331-1335.

38. Hawkes F.R., Dinsdale R., Hawkes D.L., Hussy I., 2002. Sustainable fermentative hydrogen production: challenges for process optimization. Int. J. Hydrogen Energy, 27, 1339-1347.

39. Hermann C., Idler C., Heiermann M., 2015. Improving aerobic stability and biogas production of maize silage using silage additives. Bioresource Technology, 197, 393-403.

40. Hobson P.N., Bousfield S., Summers R., Kirsch E.J., 1974. Anaerobic digestion of organic matter. Crit Rev Environ Sci Technol, 4, 131-191.

41. Hong C., Haiyun W., 2010. Optimization of volatile fatty acid production with co-substrate of food wastes and dewatered excess sludge using response surface methodology. Bioresource Technol., 101, 5487-5493.

42. Ivanova G., Rákhely G., Kovács K.L., 2009. Thermophilic biohydrogen production from energy plants by Caldicellulosiruptor saccharolyticus and comparison with related studies. Int J Hydrogen Energy, 34, 3659-3670.

43. Jackson D.D., Ellms J.W., 1896. On odors and tastes of surface waters with special reference to Anabaena, a microscopial organism found in certain water supplies of Massachusetts. Rep Mass State Board Health, 410-20.

44. Karlsson A., Vallin L., Ejlertsson J., 2008. Effects of temperature, hydraulic retention time and hydrogen extraction rate on hydrogen production from the fermentation of food industry residues and manure. Int J Hydrogen Energy, 33, 953-962.

45. Kazimierowicz J., 2014. Organic waste used in agricultural biogas plants. Journal of Ecological Engineering, 15, 2, 88-92.

46. Keasling J.D., Benemann J.R., Pramanik J., Carrier T.A., Jones K.L., Van Dien S.J., 1998. A toolkit for metabolic engineering of bacteria: application to hydrogen production. In: O. Zaborsky (Ed.), Biohydrogen, Plenum Press, New York, 87-98.

47. Khanal S.K., Chen W.H., Li L., Sung S., 2004. Biological hydrogen production: effect of $\mathrm{pH}$ and intermediate products. Int. J. Hydrogen Energ, 29, 1123-1131.

48. Kim J.K., Nhat L., Chun Y.N., Kim S.W., 2008. Hydrogen production conditions from food waste by dark fermentation with Clostridium beijerinckii KCTC 1785. Biotechnol. Bioprocess, 13, 499-504.

49. Kim S.H., Han S.K., Shin H.S., 2004. Feasibility of biohydrogen production by anaerobic co-digestion of food waste and sewage sludge. Int J Hydrogen Energy, 29, 1607-1616.

50. Kotay S.M., Das D., 2008. Biohydrogen as a renewable energy resource - prospects and potentials. Int J Hydrogen Energy, 33,258-263.

51. Kotsopoulos T.A., 2009. Biohydrogen production from pig slurry in a CSTR reactor system with mixed cultures under hyper-thermophilic temperature $\left(70^{\circ} \mathrm{C}\right)$. Biomass Bioenergy, 33, 1168-1174.

52. Kozłowski K., Lewicki A., Sołowiej P., Neugebauer M., Smurzyńska A., 2016. Usage of waste whey as mono-substrate in continuous fermentation process. Energy And Clean Technologies Conference Proceedings, SGEM 2016, Vol. III: 345-350.

53. Kraemer J.T., Bagley D.M., 2007. Improving the yield from fermentative hydrogen production. Biotechnol. Lett., 29, 685-695.

54. Kumar N., Das D., 2000. Enhancement of hydrogen production by Enterobacter cloacae IIT-BT 08. Process Biochem., 35, 589-593.

55. Kuratorium für Technik und Bauwesen in der Landwirtschaft (KTBL), Faustzahlen Biogas, 2nd edition, Darmstadt; 2009 
56. Lay J., Fan K., Hwang J., Chang J., Hsu P., 2005. Factors affecting hydrogen production from food wastes by Clostridium-rich composts. J Environ Eng, 131, 595-602.

57. Lay J.J., Lee Y.J., Noike T., 1999. Feasibility of biological hydrogen production from organic fraction of municipal solid waste. Water Res., 33, 2579-2586.

58. Lee Y.W., Chung J., 2010. Bioproduction of hydrogen from food waste by pilot-scale combined hydrogen/methane fermentation. Int. J. Hydrogen Energy, 35, 11746-11755.

59. Levin D.B., Pitt L., Love M., 2004. Biohydrogen production: prospects and limitations to practical application. Int. J. Hydrogen Energy, 29, 173-185.

60. Li D., Chen H., 2007. Biological hydrogen production from steam-exploded straw by simultaneous saccharification and fermentation. Int $\mathrm{J}$ Hydrogen Energy, 32, 1742-1748.

61. Li M., Zhao Y., Guo Q., Qian X., Niu D., 2008. Bio-hydrogen production from food waste and sewage sludge in the presence of aged refuse excavated from refuse landfill. Renew Energy, 33, 2573-2579.

62. Liang T., Cheng S., Wu K., 2002. Behavioral study on hydrogen fermentation reactor installed with silicone rubber membrane. Int J Hydrogen Energy, 27, 1157-1165.

63. Mao C., Feng Y., Wang X., Ren G., 2015. Review on research achievements of biogas from anaerobic digestion. Renewable and Sustainable Energy Reviews, 45, 540-555.

64. Marszałek M., Kowalski Z., Makara A., 2014. Physicochemical and microbiological characteristics of pig slurry. Technical Transactions. Chemistry, 1, 81-91.

65. Mata-Alvarez J., Macé S., Llabrés P., 2000 Anaerobic digestion of organic solid wastes. An overview of research achievements and perspectives. Bioresour. Technol., 74, 3-16.

66. Mizuno O., Dinsdale R., Hawkes F.R., Hawkes D.L., Noike T., 2000. Enhancement of hydrogen production from glucose by nitrogen gas sparging. Bioresource Technology, 73, 59-65, 2000.

67. Monlau F., Barakat A., Trably E., Dumas C., Steyer J.P., Carrère H., 2013. Lignocellulosic materials into biohydrogen and biomethane: impact of structural features and pretreatment. Crit Rev Environ Sci Technol, 43, 260-322.

68. Multerer A., 2014. The impact of biogas raw materials on the utilized agricultural area - an assessment of alternative raw material. Anliegen Nat., $36,54-60$.

69. Murphy J.D., Rudolf B., Weiland P., Wellinger A., 2011. Biogas from Crop Digestion. IEA Bioenergy - Task 37: Energy from Biogas. http://task37. ieabioenergy.com/files/daten-redaktion/download/ publi-task37/Update_Energy_crop_2011.pdf; [ac- cessed 03 March 2018].

70. Naik S.N., Goud V.V., Rout P., Dalai A.K., 2010. Production of first and second generation biofuels: a comprehensive review. Renew. Sustain. Energy Rev., 14, 578-597.

71. Nath K., Das D., 2003. Hydrogen from biomass. Current Science, 85, 265-271.

72. National Center for Agricultural Support, 2018. Register of agricultural biogas producers - 02 March 2018, http://www.kowr.gov.pl/uploads/ pliki/oze/biogaz/Rejestr_wytworcow_biogazu_ rolniczego.pdf; [accessed 06 March 2018].

73. National Center for Agricultural Support, Substrates for biogas plants 2011-2016, 2017. http:// bip.kowr.gov.pl/informacje-publiczne/odnawialnezrodla-energii/biogaz-rolniczy/dane-dotyczacedzialalnosci-wytworcow-biogazu-rolniczego-wlatach-2011-2016; [accessed 06 March 2018].

74. Nazlina H.M.Y.N.H., Nor'Aini A.R., Man H.C., Yusoff M.Z.M., Hassan M.A., 2011. Microbial characterization of hydrogen-producing bacteria in fermented food waste at different $\mathrm{pH}$ values. Int. J. Hydrogen Energy, 36, 9571-9580.

75. Neshat S.A., Mohammadi M., Najafpour G.D., Lahijani P., 2017. Anaerobic co-digestion of animal manures and lignocellulosic residues as a potent approach for sustainable biogas production. Renewable and Sustainable Energy Reviews, 79, 308-322.

76. Ni M., Leung D.Y.C., Leung M.K.H., Sumathy K., 2006. An overview of hydrogen production from biomass. Fuel Process Technol. 87, 461-472.

77. Nielsen A.T., Amandusson H., Bjorklund R., Dannetun H., Ejlertsson J., Ekedahl L.G., 2001. Hydrogen production from organic waste. Int J Hydrogen Energy, 26, 547-550.

78. Oh Y.K., Kim S.H., Kim M.S., Park S., 2004. Thermophilic biohydrogen production from glucose with trickling biofilter. Biotechnol. Bioeng., 88, 690-698.

79. Panesar P.S., Kennedy J.F., Gandhi D.N., Bunko K., 2007. Bioutilisation of whey for lactic acid production. Food Chem, 105, 1-14.

80. Paska J., Surma T., 2014. Electricity generation from renewable energy sources in Poland. Renewable Energy, 71:286-294.

81. Piwowar A., Dzikuć M., Adamczyk J., 2016. Agricultural biogas plants in Poland - selected technological, market and environmental aspects. Renewable and Sustainable Energy Reviews, 58, 69-74.

82. Polish Power Exchange, 2018. Monthly market reports 2012-2018, https://tge.pl/en/155/raportymiesieczne; [accessed 05 March 2018].

83. Rahman S.N.A., Masdar M.S., Rosli M.I., Majlan E.H., Husaini T., Kamarudin S.K., Daud W.R.W., 2016. Overview biohydrogen technologies and application in fuel cell technology. Renewable and Sustainable Energy Reviews, 66,137-162. 
84. Saxena R.C., Adhikari D.K., 2009. Goyal HB, Biomass-based energy fuel through biochemical routes: a review. Renew. Sustain. Energy Rev., 13, 167-178.

85. Schröder C., Selig M., Schönheit P., 1994. Glucose fermentation to acetate, $\mathrm{CO} 2$ and $\mathrm{H} 2$ in the anaerobic hyper-thermophilic eubacterium Thermotogamaritima - Involvement of the Embden-Meyerhof pathway. Arch. Microbiol., 161, 460-470.

86. Shin H., Youn J., 2005. Conversion of food waste into hydrogen by thermophilic acidogenesis. Biodegradation, 16, 33-44.

87. Strickland L.H., 1929. The bacterial decomposition of formate. Biochem J, 23:1187

88. Tang G., Huang J., Sun Z., Tang Q., Yan C., Liu G., 2008. Biohydrogen production from cattle wastewater by enriched anaerobic mixed consortia: influence of fermentation temperature and $\mathrm{pH}$. J Biosci Bioeng, 106, 80-87.

89. Teplyakov V.V., Gassanova L.G., Sostina E.G., Slepova E.V., Modigell M., Netrusov A.I., 2002. Labscale bioreactor integrated with active membrane system for hydrogen production: experience and prospects. Int J Hydrogen Energy, 27, 1149-1155.

90. Thi N., Kumar G., Lin C., 2015. An overview of food waste management in developing countries: current status and future perspective, J. Environ. Manage., 157, 220-229.

91. Valdez-Vazquez I., Rios-Leal E., Esparza-García F., Cecchi F., Poggi-Varaldo H., 2005. Semi-continuous solid substrate anaerobic reactors for $\mathrm{H} 2$ production from organic waste: mesophilic versus thermophilic regime. Int. J. Hydrogen Energy, 30, 1383-1391.

92. Van Niel E.W.J., Budde M.A.W., de Haas G.G., van der Wal F.J., Claasen P.A.M., Stams A.J.M., 2002. Distinctive properties of high hydrogen producing extreme thermophiles. Caldicellulosiruptor saccharolyticus and Thermotoga elfii. Int. J. Hydrogen Energy, 27, 1391-1398.

93. Van Velsen A.F.M., 1979. Adaption of methanogenic sludge to high ammonia-nitrogen concentrations. Wat. Res., 13, 995-999.

94. Venetsaneas N., Antonopoulou G., Stamatelatou K., Kornaros M., Lyberatos G., 2009. Using cheese whey for hydrogen and methane generation in a two-stage continuous process with alternative $\mathrm{pH}$ controlling approaches. Bioresour Technol, 100, 3713-3717.

95. Wang X., Zhao Y., 2009. A bench scale study of fermentative hydrogen and methane production from food waste in integrated two-stage process. Int. J. Hydrogen Energy, 34, 245-254.

96. Ward A.J., Hobbs P.J., Holliman P.J., Jones D.L., 2008. Optimisation of the anaerobic digestion of agricultural resources. Bioresour. Technol., 99,
7928-7940.

97. Wędzik A., Siewierski T., Szypowski M., 2017. Green certificates market in Poland - The sources of crisis. Renewable and Sustainable Energy Reviews, 75:490-503.

98. White E.M., Latta G., Alig R.J., Skog K.E., Adams D.M., 2013. Biomass production from the U.S. forest and agriculture sectors in support of a renewable electricity standard. Energy Policy, 58, 6474.

99. Wiater J., Horysz M., 2017. Organic waste as a substrate in biogas production. Journal of Ecological Engineering, 18, 5, 226-234.

100. Wichern M., Lübken M., Horn H., 2008. Optimizing sequencing batch reactor (SBR) reactor operation for treatment of dairy wastewater with aerobic granular sludge. Water Sci. Technol 58, 1199-1206.

101. Wu X., Zhu J., Miller C., 2008. Dairy Milking Wastewater Treatment Using a Lab-Scale Sequencing Batch Reactor (SBR). Transactions of the ASABE, 51, 1057-1065.

102. Xing Y., Li Z., Fan Y.T., Hou H.W., 2010. Biohydrogen production from dairy manures with acidification pretreatment by anaerobic fermentation. Environ Sci Pollut Res, 17, 392-399.

103. Yasin N.H.M., Mumtaz T., Hassan M.A., Abd Rahman N., 2013. Food waste and food processing waste for biohydrogen production: A review. Journal of Environmental Management, 130, 375-385.

104. Yokoyama H., Waki M., Moriya N., Yasuda T., Tanaka Y., Haga K., 2007. Effect of fermentation temperature on hydrogen production from cow waste slurry by using anaerobic microflora within the slurry. Appl Microbiol Biotechnol, 74, 474-483.

105. Yun Y.M., Lee M.K., Im S.W., Marone A., Trably E., Shin S.R., Kim M.G., Cho S.K., Kim D.H., 2018. Biohydrogen production from food waste: Current status, limitations, and future perspectives. Bioresource Technology, 248, 79-87.

106. Zhang M.L., Fan Y., Xing Y., Pan C., Zhang G., Lay J., 2007. Enhanced biohydrogen production from cornstalk wastes with acidification pretreatment by mixed anaerobic cultures. Int J Hydrogen Energy, 31, 250-254.

107. Zhu J., Miller C., Li Y.C., Wu X., 2009. Swine manure fermentation to produce biohydrogen. Bioresour Technol, 100, 5472-5477.

108. Zong W., Yu R., Zhang P., Fan M., Zhou Z., 2009. Efficient hydrogen gas production from cassava and food waste by a two-step process of dark fermentation and photo-fermentation. Biomass Bioenergy, 33, 1458-1463. 